\title{
Effects of stock and culture environment on infections by Marteilia refringens and Mytilicola intestinalis in the mussel Mytilus galloprovincialis cultured in Galicia (NW Spain)
}

\author{
J. Fuentes ${ }^{1}$, A. Villalba ${ }^{1}$, C. Zapata $^{2}$, G. Alvarez ${ }^{2}$ \\ ${ }^{1}$ Centro de Investigacións Marinas, Consellería de Pesca, Marisqueo e Acuicultura, Xunta de Galicia, \\ E-36600 Vilagarcía de Arousa, Spain \\ ${ }^{2}$ Departamento de Biología Fundamental, Facultad de Biología, Universidad de Santiago de Compostela, \\ E-15706 Santiago de Compostela, Spain
}

\begin{abstract}
The effects of stock and culture environment on the prevalence of Marteilia refringens and Mytilicola intestinalis in the mussel Mytilus galloprovincialis, cultured in the Ría de Arousa (Galicia. NW Spain) were studied in a transplantation experiment. Mussel seed from 4 natural populations (stocks) of the Galician coast were transferred to culture ropes hung from the fore-part and aft-part (situations) of rafts located in 3 culture areas (sites) inside the ria. The prevalence of $M$. refringens was mainly affected by the culture site. Thus, mussels cultivated in the inner area of the ría showed significantly higher prevalences than those in the middle and outer ones. Stock and situation within the raft showed less important effects. None of the 3 factors investigated showed important effects on the prevalence of $M$. intestinalis
\end{abstract}

KEY WORDS: Mytilus galloprovincialis Marteilia refringens - Mytilicola intestinalis - Prevalence . Stock · Culture environment - Transplantation · Mussel cultivation

\section{INTRODUCTION}

Stock and culture environment are the most feasible factors to manage when a disease threatens a bivalve culture. On the one hand, less susceptible stocks could be obtained by selecting among different sources of seed. On the other hand, culture environments favourable to disease infection should be avoided. Management strategies to minimize adverse effects of the protistan parasites Perkinsus marinus and Haplosporidium nelsoni on Crassostrea virginica are based on control of these factors (Andrews 1984, Andrews \& Ray 1988, Ford \& Haskin 1988). The susceptibility of different wild stocks of Ostrea edulis to infection by Marteilia refringens and Bonamia ostreae has also been tested (Grizel 1979, Bachère \& Grizel 1985).

Cultivation of the mussel Mytilus galloprovincialis in the Galician rías (NW Spain) has not been affected by mass mortalities; however, recent evidence suggests that some pathologic problems may affect the cultured mussels. First, infections caused by several parasites have been reported in 2 extensive surveys in this region (Figueras et al. 1991, Mourelle 1993). Infections caused by the protistan Marteilia refringens and the copepod Mytilicola intestinalis showed the highest prevalences. $M$. refringens multiplies through digestive epithelia of mussels, and in heavy infections a large proportion of the epithelial surface of the host's digestive diverticula is occupied by parasites (Villalba et al. 1993b). Heavy infections by this parasite inhibit both gametogenesis and development of storage tissue in mussels (Villalba et al. 1993a). M. intestinalis inhabits digestive lumina of the host, and its effects on mussels are a matter of controversy (Theisen 1987, Davey \& Gee 1988). Second, mussel mortalities higher than normal background mortality (Sindermann 1976) have 
been found in inner areas of the rías (Villalba et al. 1993b, Fuentes et al. 1994), where prevalences of parasites are the highest (Figueras et al. 1991, Mourelle 1993). Third, total mussel production in Spain $195 \%$ of which is in Galicia) has decreased in the last few years (FAO 1992).

Mussel cultivation in Galicia is based on the transplantation of mussel seed from intertidal populations occurring at different locations along the exposed coast to rafts moored in several sheltered, nutrient-rich growing environments inside the rias (Pérez Camacho et al, 1991). To assess the relative influence of stock and growing environment on variables determining production of cultured mussels (growth rate, mortality, and infection rate) an experiment was carried out by transplanting mussels from several populations (stocks) of the Galician coast to the fore-part and aftpart (situations) of rafts located in different growing areas (sites) of the Ría de Arousa. Growth-rate and mortality data on both seed and adult mussels have been documented elsewhere (Fuentes et al. 1992, 1994). In this report, the relative influence of stock and culture environment on the prevalence of Marteilia refringens and Mytilicola intestinalis is analysed.

\section{MATERIALS AND METHODS}

Experimental design. Mussel seed (8 mo old and $<20 \mathrm{~mm}$ long) from 4 natural populations (Stocks $\mathrm{A}, \mathrm{B}$, $C, D)$ in the intertidal zone of the Galician coast were transplanted, on February 1989, to commercial mussel rafts located in 3 growing areas (Sites 1, 2, 3) in the Ría de Arousa (NW Spain; Fig. 1). Mussels of this size are free of Marteilia refringens and Mytilicola intestinalis (Mourelle 1993, Villalba et al. 1993b). From February to August 1989, mussels from each stock-site combination were grown in plastic cages and then transferred to traditional culture ropes, on which they were grown until September 1990. To obtain estimates of the within-raft variability, both cages and ropes were hung from the fore- and aft-part of the rafts (Situations FP and AP). Most Galician mussel rafts are rectangular floating structures anchored to only one point by a chain tied to one of their shorter sides. Consequently, their movement is such that one side (fore) is permanently 'up current' and the other side (aft) is permanently 'down current'.

Sampling. Mussels were sampled 3 times: late August 1989, when mussels were transferred from cages to ropes: mid-June 1990, since the prevalence of Marteilia refringens is expected to be the highest in June due to post-spawning stress (Villalba et al. 1993a); and mid-September 1990, at the end of the experiment. On each sampling date, 15 mussels were

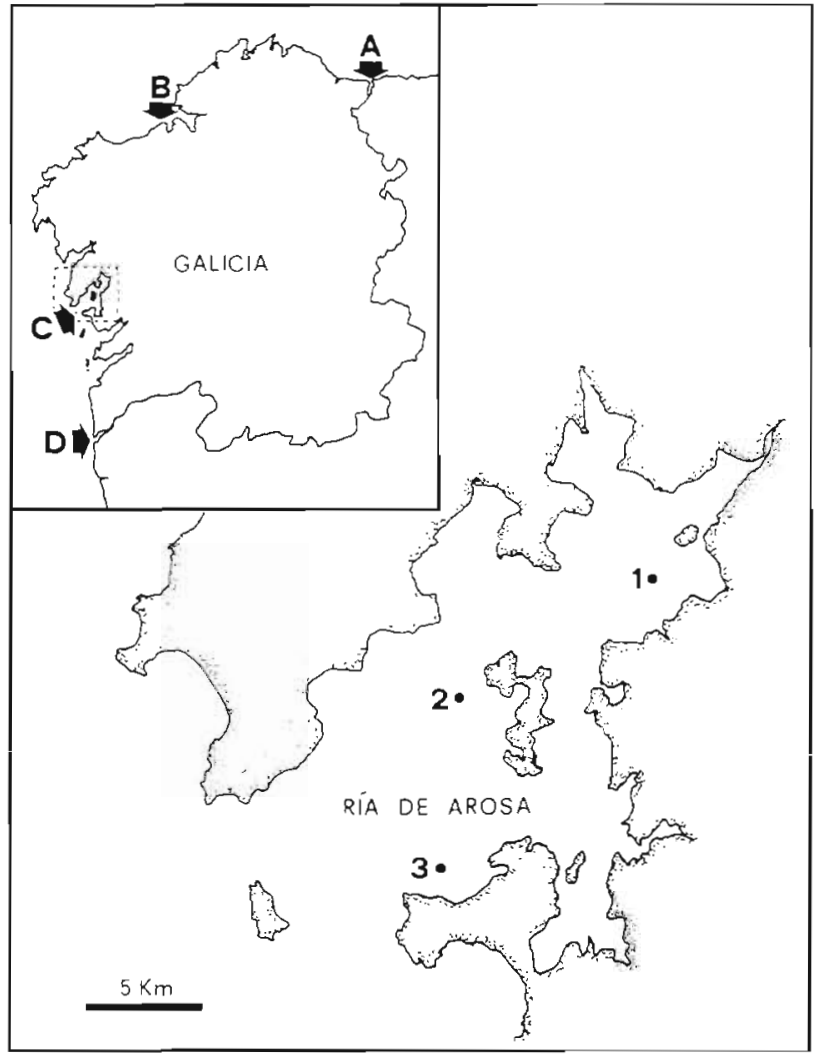

Fig. 1. Galicia and the Ría de Arousa (NW Spain), showing the sources of the 4 Mytilus galloprovincialis stocks (A, Ribadeo; $B$, Suevos; C, Sálvora; D, Camposancos) and the 3 growing sites $(1$, inner $; 2$, middle $;$, outer $)$

taken from each stock-site-situation combination. A ca $5 \mathrm{~mm}$ thick section of soft tissue containing gills and visceral mass was excised from each specimen, fixed in Davidson's solution and embedded in paraffin; $6 \mu \mathrm{m}$ thick sections were stained with Harris's hematoxylin and eosin (H\&E) and examined under light microscopy for detection of $M$. refringens and Mytilicola intestinalis. The prevalence of each parasite in every sample was estimated as: (no. of infected mussels $\times 100$ )/(total no. of mussels in the sample). Each mussel was rated according to the degree of infection by $M$. refringens, using a scale proposed by Villalba et al. (1993b): no infection, light infection, moderate infection, and heavy infection. No case of moderate infection by this parasite was found. The mean intensity of infections by M. refringens in every sample was estimated as: (no. of mussels with heavy infection $\times 100) /($ total no. of infected mussels in the sample).

Statistical analysis. The effects of stock, site, and situation within the raft on prevalences of both Marteilia refringens and Mytilicola intestinalis, and on mean intensity of $M$. refringens, were analysed by 3-way analysis of variance (ANOVA). These analyses were 
performed with a least-squares approach, using a sum of squares for $\Sigma$-restricted models (the Type III SS of the SAS/PROC GLM computer program; Spector et al. 1985). We tested the following linear model for each variable on each sampling date:

$$
\begin{gathered}
Y_{i j k}=\mu+\mathrm{st} t_{1}+\mathrm{si} j_{j}+\mathrm{su}_{k}+(\mathrm{st} \mathrm{si})_{1 j}+(\mathrm{st} \mathrm{su})_{1 k}+ \\
(\mathrm{si} \mathrm{su})_{j k}+(\text { st si su })_{i j k}
\end{gathered}
$$

where $\mu$ is the grand mean; st, si, and su are the fixed effects of stock, site and situation, respectively; (st si), (st su), and (si su) are the first-order interactions; and (st si su) is the second-order interaction, which was used as residual term. Because of requirements related to normality and homoscedasticity of the distributions, prevalence values were arcsine-transformed prior to ANOVA (Sokal \& Rohlf 1981).

\section{RESULTS}

\section{Infection by Marteilia refringens}

In August 1989, the 3 factors analysed (stock, site and situation) showed statistically significant effects on Marteilia refringens prevalence (Table 1). The grand mean value of prevalence, calculated over all stocks, sites and situations, was $8.1 \%$. The highest variation occurred among sites, with mean prevalence ranging from $4.1 \%$ and $3.1 \%$ at Sites 2 and 3 , respectively, to $16.5 \%$ at the inner Site 1 (Fig. 2). Stocks and situations within the rafts showed less variability. Interaction terms also showed significant effects on prevalence (Table 1). This means that the pattern of variation of each main factor depended on the levels of the other factors. Thus, while at Site 1 the prevalences in Stocks B and C (24.8 and $25 \%$, respectively) were significantly higher than prevalences in Stocks $A$ and D (12.5 and 3.9\%, respectively), at Sites 2 and 3 prevalences of stocks were very similar (less than $8 \%$ ). Similarly, while at Site 1 the prevalence in mussels situated at the fore-part of rafts $(23.9 \%)$ was significantly higher than at the aft-part $(9.1 \%)$, at Sites 2 and 3 prevalences in both situations were very similar (less than $5 \%$ ). In June 1990, the grand mean prevalence value was $19.6 \%$. The highest difference was detected among sites (Fig. 2), with mussels at Site 1 having a considerably higher prevalence $(42.3 \%)$ than those at Sites $2(12.0 \%)$ and $3(3.4 \%)$. Differences between both stocks and situations (Fig. 2) were not significant (Table 1). In September 1990, the pattern of variability was similar to the patterns described above. The grand mean prevalence value was $25.7 \%$. Site was the only factor that showed a statistically significant effect on prevalence (Table 1); the highest difference in prevalences occurred between Site $3(3.5 \%)$ and Site $1(52.2 \%)$.

Mean percentages of both lightly and heavily infected mussels are shown in Fig. 2. Mean intensity of infections by Marteilia refringens was not significantly different among any of the studied factors ( $p>0.05)$.

Table 1. ANOVA to analyse the effects of stock, site, and situation on the prevalence of Marteilia refringens and Mytilicola

\begin{tabular}{|c|c|c|c|c|c|c|c|c|c|}
\hline \multirow[t]{2}{*}{ Source of variation } & \multicolumn{3}{|c|}{ August 1989} & \multicolumn{3}{|c|}{ June 1990} & \multicolumn{3}{|c|}{ September 1990} \\
\hline & df & SS & F-value & $\mathrm{df}$ & SS & F-value & $\mathrm{df}$ & SS & F-value \\
\hline \multicolumn{10}{|l|}{ M. refringens } \\
\hline Stock & 3 & 0.21 & $9.61^{\circ}$ & 3 & 0.10 & $1.54 \mathrm{~ns}$ & 3 & 0.11 & $1.16 \mathrm{~ns}$ \\
\hline Site & 2 & 0.24 & $16.35 \cdots$ & 2 & 0.85 & $19.01^{\cdots}$ & 2 & 0.63 & $10.20^{\circ}$ \\
\hline Situation & 1 & 0.07 & $9.04^{*}$ & 1 & 0.04 & $1.61 \mathrm{~ns}$ & 1 & 0.00 & $0.04 \mathrm{~ns}$ \\
\hline Stock-Site & 6 & 0.47 & $10.74^{\circ}$ & 5 & 0.02 & $0.22 \mathrm{~ns}$ & 6 & 0.16 & $0.88 \mathrm{~ns}$ \\
\hline Stock-Situation & 3 & 0.18 & $8.36^{\circ}$ & 3 & 0.13 & $1.96 \mathrm{~ns}$ & 3 & 0.17 & $1.80 \mathrm{~ns}$ \\
\hline Site-Situation & 2 & 0.11 & $7.74^{\circ}$ & 2 & 0.00 & $0.04 \mathrm{~ns}$ & 2 & 0.01 & $0.23 \mathrm{~ns}$ \\
\hline Residual & 5 & 0.04 & & 4 & 0.09 & & 3 & 0.09 & \\
\hline Total & 22 & 1.20 & & 20 & 1.53 & & 20 & 2.00 & \\
\hline \multicolumn{10}{|l|}{ M. intestinalis } \\
\hline Stock & 3 & 0.04 & $0.78 \mathrm{~ns}$ & 3 & 0.04 & $1.18 \mathrm{~ns}$ & 3 & 0.04 & $0.52 \mathrm{~ns}$ \\
\hline Site & 2 & 0.32 & $10.04^{\bullet}$ & 2 & 0.01 & $0.59 \mathrm{~ns}$ & 2 & 0.02 & $0.44 \mathrm{~ns}$ \\
\hline Situation & 1 & 0.00 & $0.07 \mathrm{~ns}$ & 1 & 0.04 & $3.21 \mathrm{~ns}$ & 1 & 0.00 & $0.08 \mathrm{~ns}$ \\
\hline Stock-Site & 6 & 0.02 & $0.19 \mathrm{~ns}$ & 5 & 0.08 & $1.48 \mathrm{~ns}$ & 6 & 0.03 & $0.17 \mathrm{~ns}$ \\
\hline Stock-Situation & 3 & 0.12 & $2.39 \mathrm{~ns}$ & 3 & 0.11 & $3.30 \mathrm{~ns}$ & 3 & 0.06 & $0.72 \mathrm{~ns}$ \\
\hline Site-Situation & 2 & 0.07 & $2.12 \mathrm{~ns}$ & 2 & 0.01 & $0.55 \mathrm{~ns}$ & 2 & 0.01 & 0.16 \\
\hline Residual & 5 & 0.08 & & 4 & 0.04 & & 3 & 0.08 & \\
\hline Total & 22 & 0.66 & & 20 & 0.36 & & 20 & 0.30 & \\
\hline
\end{tabular}
intestinalis in mussels Mytilus galloprovincialis 
August 1989

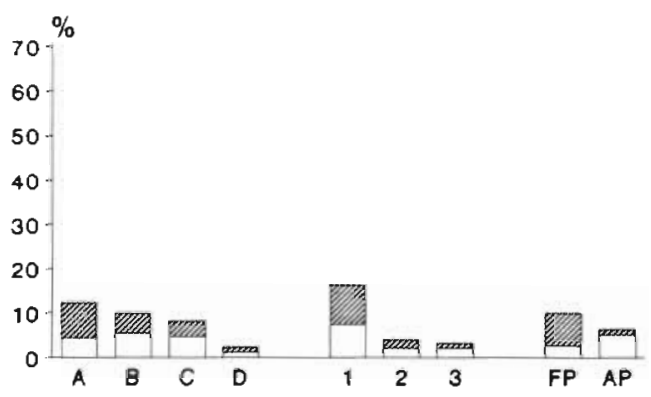

June 1990

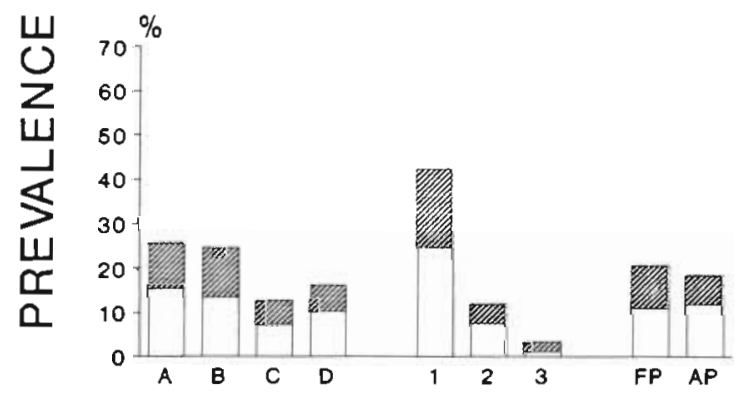

September 1990

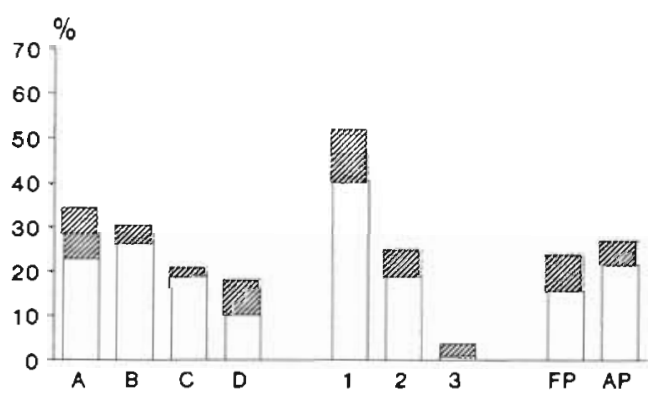

Fig. 2. Mean prevalences of Marteilia refringens (whole bars) in Mytilus galloprovincialis, on the 3 sampling dates, for each stock $(A, B, C, D)$ averaged over all sites and situations, for each site $(1,2,3)$ averaged over all stocks and situations and for each situation (fore-part: FP; aft-part: AP) averaged over all stocks and sites. Hatched portions of bars represent mean percentages of heavily infected mussels; open portions repre-

sent mean percentages of lightly infected mussels

\section{Infection by Mytilicola intestinalis}

The pattern of prevalence of Mytilicola intestinalis (Fig. 3) was different from that described for Marteilia refringens. First, grand mean values of prevalence (25.6, 61.0, and 54.0\%, in August 1989, June 1990, and September 1990, respectively) were higher than those reported for $M$. refringens. Second, none of the factors analysed (except Site in August 1989) showed significant effects on prevalence of $M$. intestinalis (Table 1).

\section{August 1989}

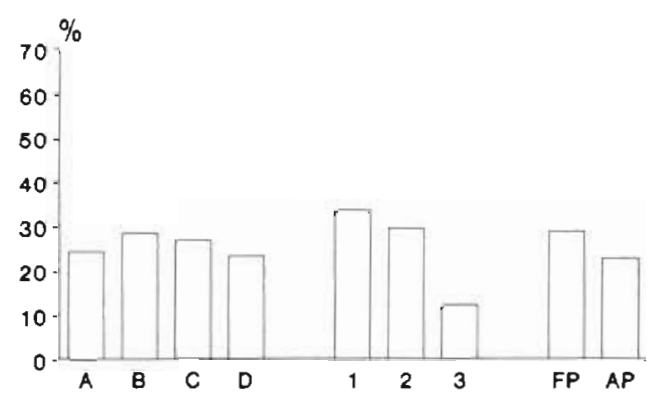

June 1990

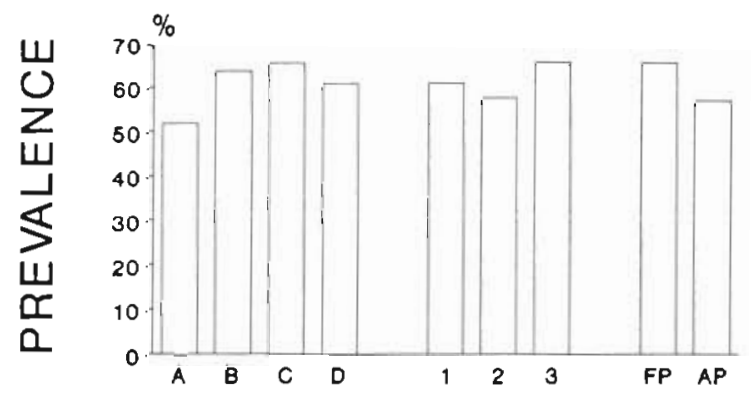

September 1990

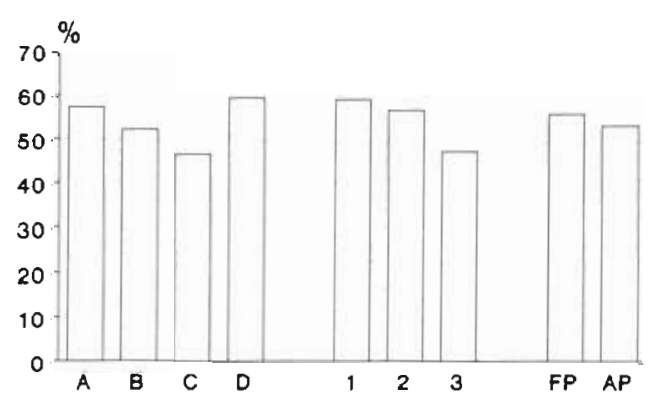

Fig. 3. Mean prevalences of Mytilicola intestinalis in Mytilus galloprovincialis, on the 3 sampling dates, for each stock $(A, B, C, D)$ averaged over all sites and situations, for each site $(1,2,3)$ averaged over all stocks and situations and for each situation (fore-part: FP; aft-part: AP) averaged over all stocks and sites

\section{DISCUSSION}

Prevalence of marteiliasis affecting cultured mussels Mytilus galloprovincialis in the Ría de Arousa is primarily influenced by site of cultivation. Mussels cultivated in the inner part of the ría (Site 1) showed higher prevalences than those located in the middle and outer ones (Sites 2 and 3, respectively). Stock, situation of the mussels within the rafts and interaction terms caused less important effects, only slightly significant in August 1989. In contrast, prevalence of Mytilicola intestinalis in mussels was not significantly affected by 
any of the factors, except by site in August 1989, which showed a slightly significant effect.

This site-dependent prevalence of Marteilia refringens could explain the high variability of mussel mortality detected among the same experimental sites in 2 previous studies (Villalba et al. 1993b, Fuentes et al. 1994). The highest percentages of annual cumulative mortality calculated from both reports (27 and 23\%, respectively) occurred at Site 1 , whereas significantly lower percentages were recorded at Site 2 (12 and $14 \%$, respectively) and Site $3(10 \%)$. A similar association between mussel mortality and infection by Mytilicola intestinalis cannot be deduced from this experiment. Effects of this copepod on mussels are a matter of controversy (Theisen 1987, Davey \& Gee 1988). Although a slightly significant detrimental effect by $M$. intestinalis on host condition was detected in the Galician rías, it was far less important than that by $M$. refringens (Villalba 1994). Other pathogens and parasites found on the mussels of the Ría de Arousa showed very low prevalences and/or lack of a well-defined pathological effect (Figueras et al. 1991, Mourelle 1993) and, therefore, should be excluded as important mortality-causing agents. Pollution should also be excluded since no important contaminants are discharged into the ría. However, a cause and effect relationship between marteiliasis and mortality of mussels cannot be definitively established and testing of this must wait until artificial transmission experiments can be performed. Unfortunately, all attempts to artificially transmit representatives of Marteilia into bivalves have failed, probably due to the necessity of an unknown intermediate host (Alderman 1979, Balouet 1979, Grizel 1985).

Mean intensity of infections by Marteilia refringens indicated that after mussels became infected, the percentage of those in which infection progressed (reaching the 'heavy infection' class) was not significantly different among sites. A similar observation was reported by Lester (1986) for the Sydney rock oyster Saccostrea commercialis. This author suggested that oysters became infected by Marteilia sydneyi only in areas of low salinity conditions associated with heavy rain, but that salinity had no significant effect on the progression of the infection. Although salinity at Site 1 is occasionally below 15 ppt (Landín 1987, Centro Galego de Control da Calidade do Medio Mariño 1993), an association between salinity and infection by $M$. refringens can only be tentatively suggested. Other factors associated with the estuarine gradient, such as the abundance of infective particles, cannot be excluded.

Stocks used as sources of seed in this experiment did not show significant differences in the prevalence of either Marteilia refringens or Mytilicola intestinalis on most of the sampling dates. A slightly significant difference between stocks $(p<0.05$ ) with respect to $M$. refringens prevalence was detected in August 1989, when infection by this parasite was still very low. However, stocks transplanted from the northern coast of Galicia ( $A$ and $B$ ) showed higher mean prevalences of $M$. refringens than stocks transplanted from the southern coast $(C$ and $D)$ on the 3 sampling dates. Similar results ( $A$ and $B$ higher than $C$ and $D$ ) have also been described for the mortality of both seed and adult mussels of the same stocks (Fuentes et al. 1992, 1994). The northern coast of Galicia is less intensively affected by marteiliasis than the southern coast (Villalba et al. 1993b) and, therefore, mussels from the latter area could have developed some resistance to the infection by the parasite. Development of resistance to parasites has been reported in natural populations of both the Eastern oyster Crassostrea virginica (Andrews \& Hewatt 1957, Andrews \& Ray 1988, Ford 1988) and the flat oyster Ostrea edulis (Elston et al. 1987).

Our study has also revealed that the situation of the mussels within the raft (fore-part vs aft-part) does not have a significant influence on the infestation by Marteilia refringens and Mytilicola intestinalis. Important differences in available food (Cabanas et al. 1980), scope for growth (Navarro et al. 1991), and growth rate (Fuentes et al. 1992, 1994) existing between the foreand aft-part of the rafts do not result in different rates of mussel infection by these parasites.

Acknowledgements. We are very grateful to mussel farmers Raúl Fraga, Armando Otero and José Padín who kindly allowed the use of their mussel rafts to carry out this study. Isabel Reyero, Ramón Giráldez and Azucena RodríguezPaton helped with the field and laboratory work. Maribel Meléndez, Teresa Andrade and Elena Penas provided assistance with histological techniques. This investigation was supported by funds from the Conselleria de Pesca, Marisqueo e Acuicultura (Xunta de Galicia), to J.F.

\section{LITERATURE CITED}

Alderman DJ (1979) Epizootiology of Marteilia refringens in Europe. Mar Fish Res 41:67-69

Andrews DJ (1984) Epizootiology of diseases of oysters (Crassostrea virginical, and parasites of associated organisms in eastern North America. Helgoländer Meeresunters 37: $149-166$

Andrews DJ, Hewatt WG (1957) Oyster mortality studies in Virginia. II. The fungus disease caused by Dermocystidium marinum in oysters of Chesapeake Bay. Ecol Monogr 27:1-26

Andrews DJ, Ray SM (1988) Management strategies to control the disease caused by Perkinsus marinus. Am Fish Soc Spec Publ 18:257-264

Bachère E, Grizel H (1985) Réceptivité de trois populations naturelles d'huitres plates Ostrea edulis L. au protozoaire Bonamia ostreae (Pichot et al., 1980). Rev Trav Inst Pêches marit 47:237-240 
Balouet G (1979) Marteilia refringens - considerations on the life cycle and development of Abers disease in Ostrea edulis. Mar Fish Rev 41:64-66

Cabanas JM, González JJ, Marino J, Pérez A, Román G (1980) Estudio del mejillón y de su epifauna en los cultivos flotantes de la Ría de Arosa: observaciones previas sobre la retención de partículas y la biodeposición de una batea. Bol Inst esp Oceanog 268:44-50

Centro Galego de Control da Calıdade do Medio Marino (1993) Condicións oceanográficas e fitoplancton. Informe anual 1992. Consellería de Pesca, Marisqueo e Acuicultura, Xunta de Galicia, Santiago de Compostela

Davey JT, Gee JM (1988) Mytilicola intestinalis, a copepod parasite of blue mussel. Am Fish Soc Spec Publ 18:64-73

Elston RA, Kent ML, Wilkinson MT (1987) Resistance of Ostrea edulis to Bonamia ostreae infection. Aquaculture $64: 237-242$

FAO (1992) Aquaculture production 1984-1990. FAO Fisheries circular 815 (Rev 4)

Figueras AJ, Jardon CF, Caldas JR (1991) Diseases and parasites of rafted mussels (Mytilus galloprovincialis Lmk): preliminary results. Aquaculture 99:17-33

Ford SE (1988) Host-parasite interactions in oysters, Crassostrea virginica, selected for resistance to Haplosporidium nelsoni (MSX): survival mechanisms against a natural pathogen. Am Fish Soc Spec Publ 18:206-224

Ford SE, Haskin HH (1988) Management strategies for MSX (Haplosporidium nelsoni) disease in Eastern oysters. Am Fish Soc Spec Publ 18:249-256

Fuentes J, Reyero I, Zapata C, Alvarez G (1992) Influence of stock and culture site on growth rate and mortality of mussels (Mytilus galloprovincialis Lmk.) in Galicia, Spain. Aquaculture 105:131-142

Fuentes J, Reyero I, Zapata C. Alvarez G (1994) Production traits of the mussel Mytilus galloprovincialis cultured in Galicia (NW of Spain): relative effects of source of seed and growing environment. Aquaculture 122:19-31

Grizel H (1979) Marteilia refringens and oyster disease Recent observations. Mar Fish Res 41:38-39

Grizel H (1985) Etude des récentes épizooties de l'huitre plate Ostrea edulis Linné et de leur impact sur l'ostréiculture bretonne. Thèse d'Etat, Université de Montpellier

Responsible Subject Editor: A. K. Sparks, Seattle, Washington, USA
Landín A (1987) Salinidades y temperaturas de la ría de Arosa (NW España) a lo largo de un año. Cuad Marisq Publnes téc 9:233-264

Lester RJG (1986) Field and laboratory experiments on the oyster parasite Marteilia sydneyi. In: Cremin M, Dobson C. Moorhouse DE (eds) Parasite lives. Papers on parasites, their hosts and their associations. University of Queensland Press, Brisbane, p 33-40

Mourelle SG (1993) Estudio patológico del mejillón cultivado en Galicia (Mytilus galloprovincialis Lmk.). Tesis doctoral. Universidad de Santiago de Compostela

Navarro E, Iglesias JIP, Pérez Camacho A, Labarta U, Beiras R (1991) The physiological energetics of mussels (Mytilus galloprovincialis Lmk.) from different cultivation rafts in the Ría de Arosa (Galicia, N.W. Spain). Aquaculture 94:197-212

Pérez Camacho A, González R, Fuentes J (1991) Mussel culture in Galicia (N.W. Spain). Aquaculture 94:263-278

Sindermann CJ (1976) Oyster mortalities and their control. In: Pillay TVR, Dill WA (eds) Advances in aquaculture. Fishing New Books Ltd, Farnham, p 349-361

Sokal RR, Rohlf FJ (1981) Biometry. Freeman, New York

Spector P, Goodnight JH, Sall JP, Sarle WS (1985) The GLM procedure. In: Joyner SP (ed) SAS/STAT guide for personal computers, Version 6 edn. SAS Institute Inc, Cary, NC, p 183-260

Theisen BF (1987) Mytilicola intestinalis Steuer and the condition of its host Mytilus edulis L. Ophelia 27:77-87

Villalba A (1994) Estudio de la marteiliasis del mejillón. Efectos de esta enfermedad en el mejillón cultivado en las Rías Gallegas. Tesis doctoral, Universidad de Santiago de Compostela

Villalba A, Mourelle SG, Carballal MJ, López MC (1993a) Effects of infection by the protistan parasite Marteilia refringens on the reproduction of cultured mussels Mytilus galloprovincialis in Galicia (NW Spain). Dis aquat Org 17:205-213

Villalba A, Mourelle SG, Carballal MJ, López MC, Azevedo C (1993b) Marteiliasis affecting cultured mussels Mytilus galloprovincialis of Galicia (NW Spain). I. Etiology, phases of the infection, and temporal and spatial variability in prevalence. Dis aquat Org 16:61-72

Manuscript first received: Apri] 6, 1994

Revised version accepted: November 15, 1994 